\title{
Behavior of Low Grade Steel Fiber Reinforced Concrete Made with Fresh and Recycled Brick Aggregates
}

\author{
Md. Shariful Islam ${ }^{1}$ and Mohammad Al Amin Siddique ${ }^{2}$ \\ ${ }^{1}$ Department of Civil Engineering, World University of Bangladesh, Dhaka 1205, Bangladesh \\ ${ }^{2}$ Department of Civil Engineering, Bangladesh University of Engineering and Technology, Dhaka 1000, Bangladesh \\ Correspondence should be addressed to Mohammad Al Amin Siddique; alamin@ce.buet.ac.bd
}

Received 7 December 2016; Accepted 16 February 2017; Published 16 March 2017

Academic Editor: Arnaud Perrot

Copyright (c) $2017 \mathrm{Md}$. Shariful Islam and Mohammad Al Amin Siddique. This is an open access article distributed under the Creative Commons Attribution License, which permits unrestricted use, distribution, and reproduction in any medium, provided the original work is properly cited.

\begin{abstract}
In recent years, recycled aggregates from construction and demolition waste (CDW) have been widely accepted in construction sectors as the replacement of coarse aggregate in order to minimize the excessive use of natural resources. In this paper, an experimental investigation is carried out to observe the influence of low grade steel fiber reinforcements on the stress-strain behavior of concrete made with recycled and fresh brick aggregates. In addition, compressive strength by destructive and nondestructive tests, splitting tensile strength, and Young's modulus are determined. Hooked end steel wires with $50 \mathrm{~mm}$ of length and an aspect ratio of 55.6 are used as fiber reinforcements in a volume fraction of $0 \%$ (control case), $0.50 \%$, and 1.00\% in concrete mixes. The same gradation of aggregates and water-cement ratio $(w / c=0.44)$ were used to assess the effect of steel fiber in all these concrete mixes. All tests were conducted at 7,14, and 28 days to perceive the effect of age on different mechanical properties. The experimental results show that around 10\% 15\% and 40\% 60\% increase in 28 days compressive strength and tensile strength of steel fiber reinforced concrete, respectively, compared to those of the control case. It is observed that the effect of addition of $1 \%$ fiber on the concrete compressive strength is little compared to that of $0.5 \%$ steel fiber addition. On the other hand, strain of concrete at failure of steel fiber reinforced concrete has increased almost twice compared to the control case. A simple analytical model is also proposed to generate the ascending portions of the stress-strain curve of concrete. There exists a good correlation between the experimental results and the analytical model. A relatively ductile failure is observed for the concrete made with low grade steel fibers.
\end{abstract}

\section{Introduction}

At present, steel fiber reinforced concrete (SFRC) is widely used in many applications such as concrete pavements, patching repair of hydraulic structures, overlays, thin shells, and precast concrete [1]. Plain concrete is relatively brittle and it has low tensile strength, typically only around $1 / 10$ th of its compressive strength [2]. Therefore, steel reinforcement bar is normally used to reinforce the regular concrete. The mechanism of randomly distributed discrete discontinuous fibers is to make a bridge across the cracks that provide some ductility after cracking [2]. If the fibers are strong enough and sufficiently bonded to the material, then they allow fiber reinforced concrete (FRC) to carry notable amount of stresses over a relatively great rupture strain capacity in the postcracking stage $[3,4]$. To enhance the energy absorption capacity and toughness of the materials and increase the tensile, shear, and flexural strengths of concrete, a number of research studies are available [5-9]. In addition, reduction of the permeability of concrete and thereby alleviation the flow of water were also studied. An application of different types of fibers to create higher impact, abrasion, and shatter resistance in the concrete was also investigated [10-12]. According to the point of sustainability, the use of steel fiber reinforced concrete may increase the environmental impact of the plain concrete due to energy consumption and $\mathrm{CO}_{2}$ emissions related to the production and shipping of the fibers. However, fiber reinforced concrete can extend the maintenance free life of the structures and thus reduce the overall environmental impact of the construction [13]. To enhance the environmental performance of the steel fiber reinforced concrete, studies have been conducted regarding 
the use of metal waste recycled fibers as reinforcements [14-16] and the use of recycled aggregates to replace the natural aggregates [17-19]. Though the use of construction and demolition waste as recycled aggregates in substitution of natural aggregate has been vindicated to be a good solution to reduce the high consumption of natural resources [20,21], the structural behavior of the CDW-concrete is not yet fully learnt and its use as structural material is limited. Regarding the properties of CDW-concrete, it has been reported that the amount of recycled aggregates influences several properties of this type of concrete [22, 23]. Therefore, an experimental study has been conducted to understand the behavior of mechanical properties of low grade steel fiber reinforced concrete made with recycled aggregates as well as fresh brick aggregates.

For structural analysis as well as design, a complete stress-strain diagram of a material in compression is needed. To understand the behavior of stress-strain curves more deeply, besides the experimental results, an analytical model is also important. For aiding in this, a number of empirical expressions for the stress-strain curve of normal concrete have been proposed by Wee et al. [24], Carreira and Chu [25], Wang et al. [26], Popovics [27], Desayi and Krishnan [28], and Hognestad et al. [29]. However, the stress-strain behavior of steel fiber reinforced concrete is not fully yet understood. The main problem of these equations is that the effect of fiber has not been considered for the parameter given as constant in the proposed equations. Fanella and Naaman [30] developed an analytical expression to predict the complete stress-strain curve of fiber reinforced mortar taking into consideration the shape of fiber, volume fraction, and fiber geometry. Similar type of equations for the stressstrain curve of SFRC under uniaxial compression of plain concrete has been proposed by Ezeldin and Balaguru [31]. This expression involves a parameter of material $\beta$, which is to be calculated from the physical properties of the stressstrain diagram of concrete. This equation offered to evaluate the parameter $\beta$ is for hooked end steel fibers. Here, $\beta$ is a dimensionless parameter and it depends on the shape of the stress-strain curve. In the present study, stress-strain behavior of the steel fiber reinforced concrete was modeled based on the similar equation used by Ezeldin and Balaguru [31] and Nataraja et al. [5] and is compared with the obtained results.

For the existing structures, sometimes it has become necessary to assess the strength of concrete for different structural members. Destructive tests such as core cutting may become vulnerable for the critical deficient structural members of structures. Nondestructive tests become necessity for this case to assess the strength of concrete. Therefore, another objective of this paper is to determine the compressive strength of steel fiber reinforced recycled aggregate concrete by using Rebound hammer tests. In summary, the main objectives of this paper are to investigate the influence of addition of low grade steel fibers on compressive stress-strain behavior of concrete made with recycled and fresh brick aggregates as well as compressive strength determination by destructive and nondestructive tests. Splitting tensile strength in addition modulus of elasticity of concrete will be assessed experimentally. In addition, stress-strain behavior of steel
TABLE 1: Physical and chemical properties of the Portland composite cement.

\begin{tabular}{lllc}
\hline $\begin{array}{l}\text { Sl. } \\
\text { number }\end{array}$ & Properties of cement & Value \\
\hline$(1)$ & Initial setting time (min) & 110 \\
$(2)$ & Final setting time (min) & & 290 \\
$(3)$ & Compressive strength (MPa) & 28 days & 31 \\
$(4)$ & Normal consistency (\%) & & 28.25 \\
& & Clinker (\%) & $70-79$ \\
$(5)$ & Chemical composition & Fly ash, slag, & $21-25$ \\
& & limestone (\%) & \\
(6) & Specific gravity $\left(\mathrm{g} / \mathrm{cm}^{3}\right)$ & Gypsum (\%) & $0-5$ \\
\hline
\end{tabular}

fiber reinforced concrete made with both types of aggregates will be assessed analytically.

\section{Experimental Program}

The experimental sequence was designed to evaluate the mechanical properties of low grade steel fiber reinforced concrete using hook end steel fibers. Six cases have been considered in the present study to assess the effect of addition of steel fiber on the mechanical properties of SFRC. Plain concrete (control case) is made with fresh bricks and recycled brick aggregates, which are $0 \%$ fiber replacements, and two cases of steel fiber reinforced concrete with $0.5 \%$ and $1 \%$ fiber additions. A trial mix design is made to check the compatibility before making the final concrete mix design. Water-cement ratio $(w / c)=0.44$, fine aggregate (sand) to coarse aggregate ratio $(s / a)=0.44$, and cement content of $390 \mathrm{~kg} / \mathrm{m}^{3}$ are used without any chemical admixture. All specimens have been tested at the ages of 7, 14, and 28 days to evaluate the effect of age of specimens on the mechanical properties of concrete.

2.1. Materials. An extensive laboratory testing has been carried out to obtain the properties of fresh brick aggregate, recycled brick aggregate, fine aggregate (sand), cement, steel fiber, and water which are given in next subsections.

2.1.1. Cement and Water. The physical and chemical properties of used Portland composite cement (CEM II/B-M) are presented in Table 1 . The setting time was determined according to the ASTM standard C191 [32]. The normal consistency of cement was measured as per ASTM standard C187 [33]. Normal tap water was used in all types of concrete mixes.

2.1.2. Coarse and Fine Aggregates. Fresh bricks were collected from local market in Dhaka city. Dismantled concrete blocks were collected from the structural members (beams, columns, and slabs) of a 5 storied demolished residential building of 30 years old as shown in Figure 1. The collected samples of concrete were broken into small pieces manually 
TABLE 2: Properties of aggregates used in the present study.

\begin{tabular}{lcccc}
\hline Sl. number & Name of properties & Fresh brick aggregate & Recycled brick aggregate & Fine aggregate \\
\hline$(1)$ & Bulk specific gravity (OD) & 1.83 & 1.78 & 2.26 \\
$(2)$ & Bulk specific gravity (SSD) & 2.10 & 2.02 & 2.36 \\
$(3)$ & Apparent specific gravity & 2.34 & 1096 & 2.53 \\
$(4)$ & Unit weight (OD) $\left(\mathrm{kg} / \mathrm{m}^{3}\right)$ & 1000 & 1245 & 1573 \\
$(5)$ & Unit weight (SSD) $\left(\mathrm{kg} / \mathrm{m}^{3}\right)$ & 1120 & 14 & 1666 \\
$(6)$ & Absorption capacity (\%) & 12 & 40 & 5.86 \\
$(7)$ & Void content (\%) & 4 & 6.61 & 26.28 \\
$(8)$ & Fineness modulus (FM) & 5.91 & & 3.00 \\
\hline
\end{tabular}

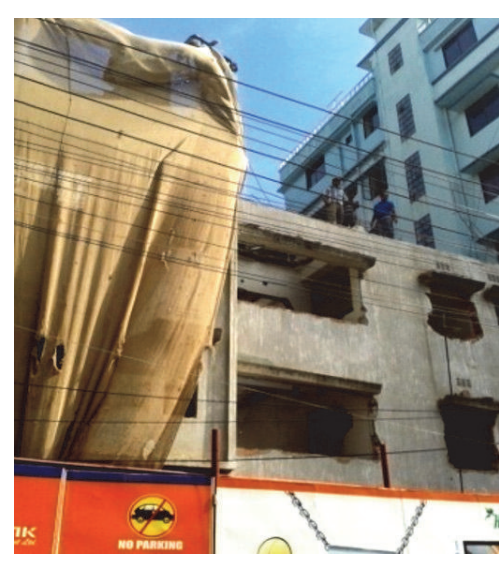

(a)

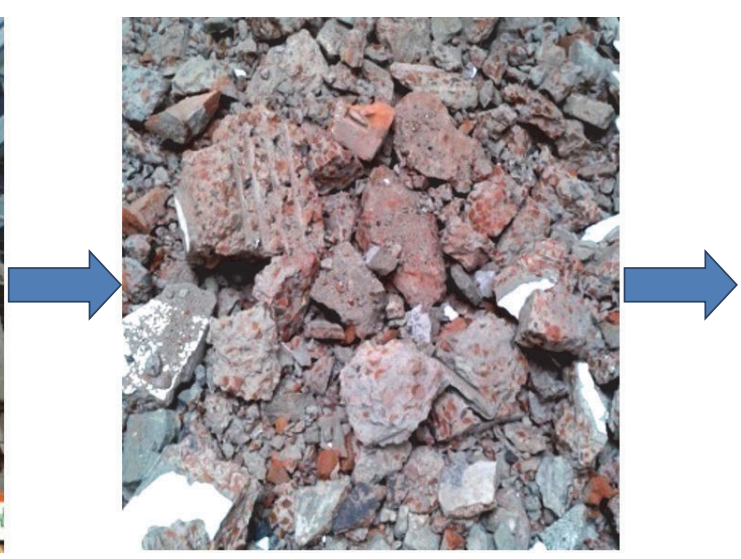

(b)

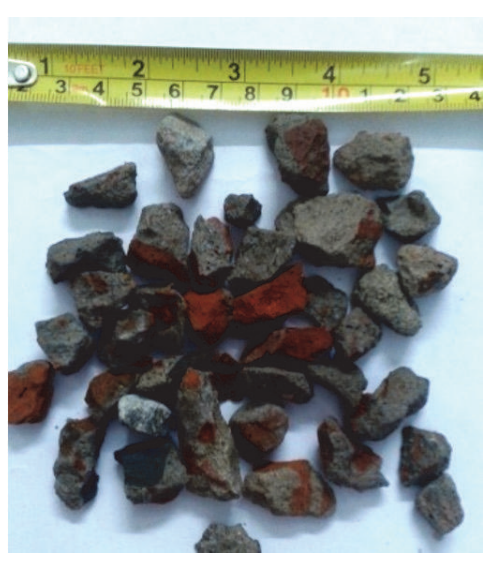

(c)

FIGURE 1: (a) Demolished building, (b) block, and (c) recycled brick aggregate.

to have a size of $19 \mathrm{~mm}$ downgraded. Sand was collected from the rivers in Sylhet district of Bangladesh is called "Sylhet Sand" and was used as fine aggregate. Both the aggregates were then sieved to have a standard grading according to ASTM C33-93 [34]. The overall moisture states of recycled aggregate may affect the workability and strength of concrete due to the higher absorption capacity compared to the fresh aggregates [35]. To maintain the saturated surface dry (SSD) condition, both aggregates were washed properly to avoid the dust and were dried in the laboratory. The oven dry (OD) basis unit weight and SSD basis unit weight as well as void content were determined according to the ASTM C29 [36]. Rodding method was used to calculate the unit weight of the aggregates. Specific gravity and absorption capacity of both the aggregates were determined according to ASTM standard C127 [37]. Table 2 shows the properties of all aggregates that have been tested in the laboratory.

2.1.3. Properties of Low Grade Steel Fiber and Method of Preparation of Specimens. Steel fiber having different sizes of diameter is generally found locally in Bangladesh. Hooked end steel fiber is used in this study to assess the effect of fiber addition on both the strength and the ductility of concrete. Table 3 shows the properties of fibers that have been tested in the laboratory. In general, it is simple and easier to make different shapes fiber but it takes more time to prepare as there is
TABle 3: Properties of steel fiber used in the present study.

\begin{tabular}{lcc}
\hline Sl. number & Name of properties & Value \\
\hline$(1)$ & Length L $(\mathrm{mm})$ & 50 \\
$(2)$ & Diameter D $(\mathrm{mm})$ & 0.9 \\
$(3)$ & Aspect ratio $(\mathrm{L} / \mathrm{D})$ & 55.56 \\
$(4)$ & Specific gravity & 6.0 \\
$(5)$ & Unit weight $\left(\mathrm{kg} / \mathrm{m}^{3}\right)$ & 6000 \\
$(6)$ & Tensile strength $(\mathrm{MPa})$ & 220 \\
\hline
\end{tabular}

no mechanical setup. After collecting the fiber from a local market, a heavy cutter was used to cut the whole bundle of wires manually. Fiber wire straightening was accomplished after cutting the bundle wires. The fiber was then cut into small pieces as the required length and it was pressed between two spikes sited on a wooden frame to make two bends at angle of $120^{\circ}$. Finally, the length of fiber was checked to obtain the desired sample size of $50 \mathrm{~mm}$. The whole working procedure of preparation of steel fiber sample is shown in Figure 2.

2.2. Concrete Mix Proportion. The concrete mixes were divided into two groups: plain concrete and steel fiber reinforced concrete. Here, B SF 0\% and RB SF 0\% mean brick 
TABLE 4: Details of concrete mixes considered in the present study.

\begin{tabular}{lcccccc}
\hline Sl. number & Cases & Cement $\left(\mathrm{kg} / \mathrm{m}^{3}\right)$ & Sand $\left(\mathrm{kg} / \mathrm{m}^{3}\right)$ & Coarse aggregate $\left(\mathrm{kg} / \mathrm{m}^{3}\right)$ & Water $\left(\mathrm{kg} / \mathrm{m}^{3}\right)$ & Steel fiber $\left(\mathrm{kg} / \mathrm{m}^{3}\right)$ \\
\hline$(1)$ & B SF 0\% & 390 & 716.4 & 798 & 171.6 & 0 \\
$(2)$ & B SF 0.5\% & 390 & 716.4 & 798 & 71.6 & 171.6 \\
$(3)$ & B SF 1\% & 390 & 716.4 & 798 & 171.6 & 60 \\
$(4)$ & RB SF 0\% & 390 & 716.4 & 768 & 171.6 & 0 \\
$(5)$ & RB SF 0.5\% & 390 & 716.4 & 768 & 171.6 & 30 \\
$(6)$ & RB SF 1\% & 390 & 716.4 & 768 & 60 \\
\hline
\end{tabular}

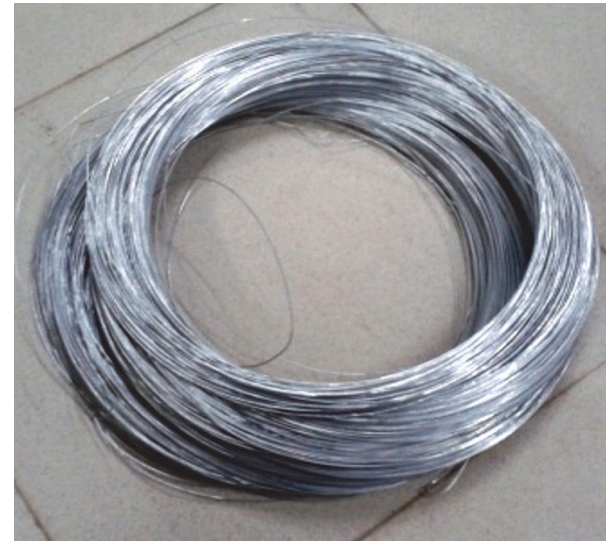

(a)

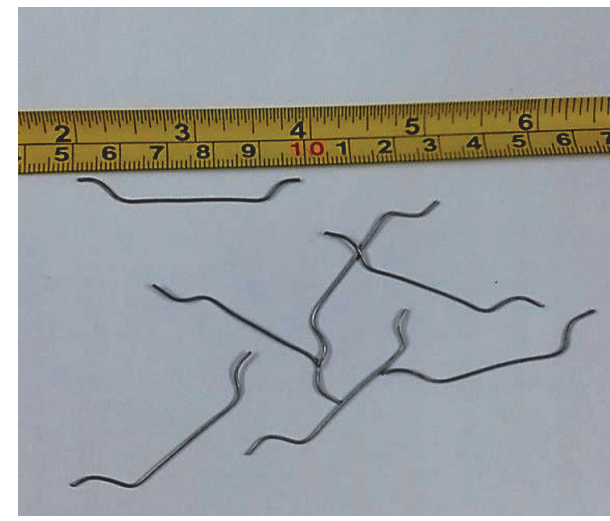

(c)

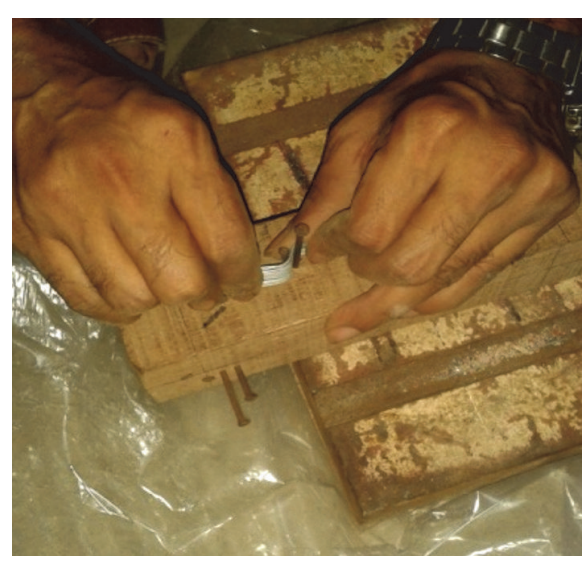

(b)

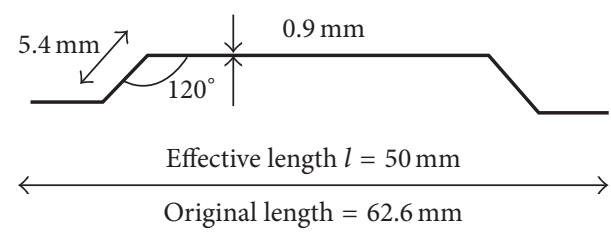

(d)

FIgURE 2: (a) Rolled steel fiber, (b) bending of fiber, (c) prepared steel fiber, and (d) size \& geometry of fiber.

aggregate $(\mathrm{B})$ and recycled brick aggregate $(\mathrm{RB})$ concrete made with $0 \%$ addition of steel fiber (SF). Similarly, $0.5 \%$ or $1 \%$ represents the concrete made with $0.5 \%$ or $1 \%$ addition of steel fiber. To observe the effect of SF, the same water to cement $(w / c=0.44)$ ratio and sand to coarse aggregate $(s / a=0.44)$ ratio were used in all the concrete mixes. In this study, addition of $1 \%$ steel fibers by volume will increase concrete unit weight by $60 \mathrm{~kg} / \mathrm{m}^{3}$. Table 4 shows the concrete mixes used in the present study.

2.3. Mixing, Casting, and Curing of Concrete. Automated mixture machine is used for mixing of concrete. Speed of the machine used is 30-35 revolutions per minute. To ensure the quality strength in the matrix, the procedure which is followed sequentially for mixing concrete is as (i) addition of the coarse aggregate; (ii) addition of $70 \%$ of the water; (iii) addition of cement; (iv) addition of the remaining portion of water and lastly; and (v) addition of the fine aggregate. A mixing time of 8-10 min was used to ensure the homogeneity of the concrete [5]. When fibers are used, they are dispersed manually during this period of mixing ingredients of concrete. Figure 3(a) shows the ingredients mixing procedure for concrete. In this study, slump test was conducted to measure the workability. Slump cone having a dimension of $300 \mathrm{~mm}\left(12^{\prime \prime}\right)$ in height, $100 \mathrm{~mm}\left(4^{\prime \prime}\right)$ diameter in top, and 


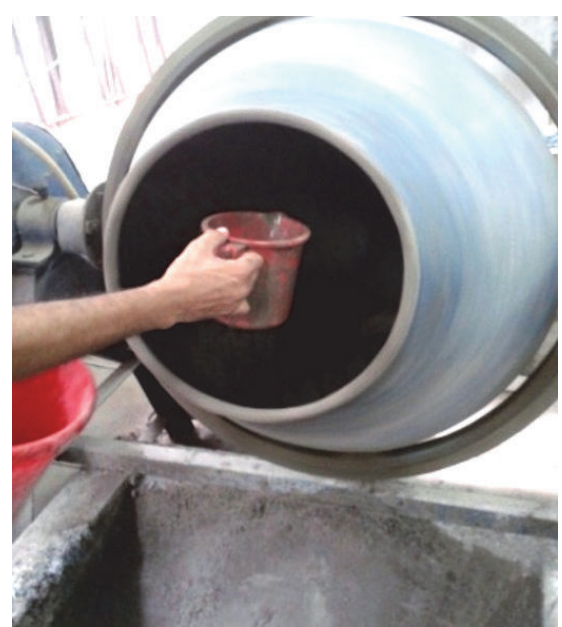

(a)

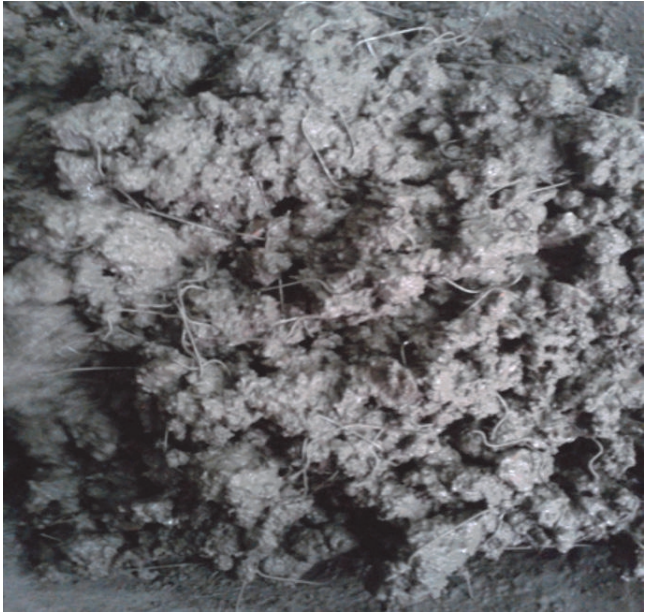

(b)

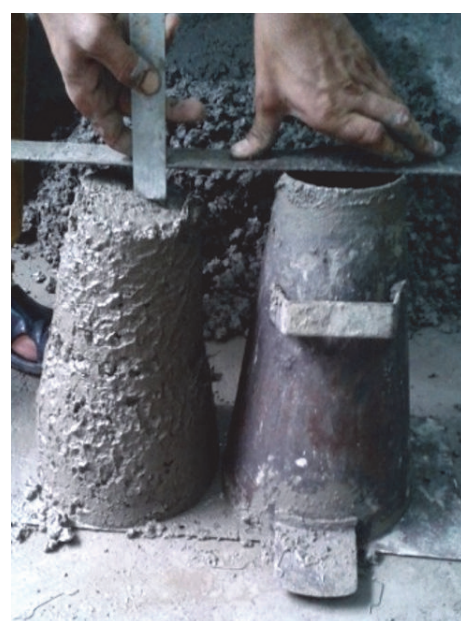

(c)

Figure 3: (a) Concrete mixing, (b) after mixing, and (c) slump test.

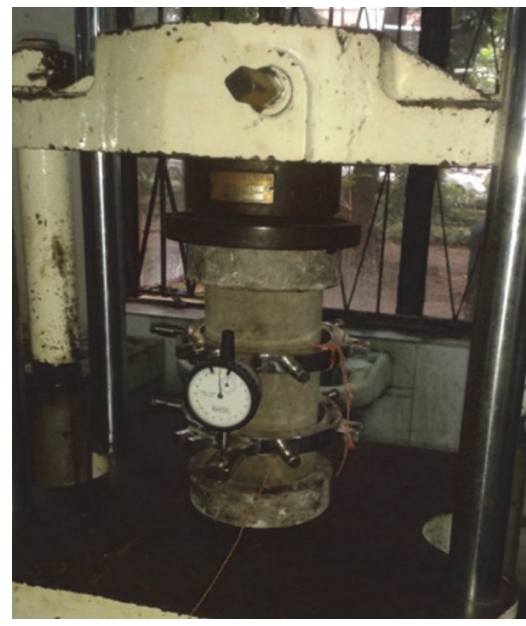

(a)

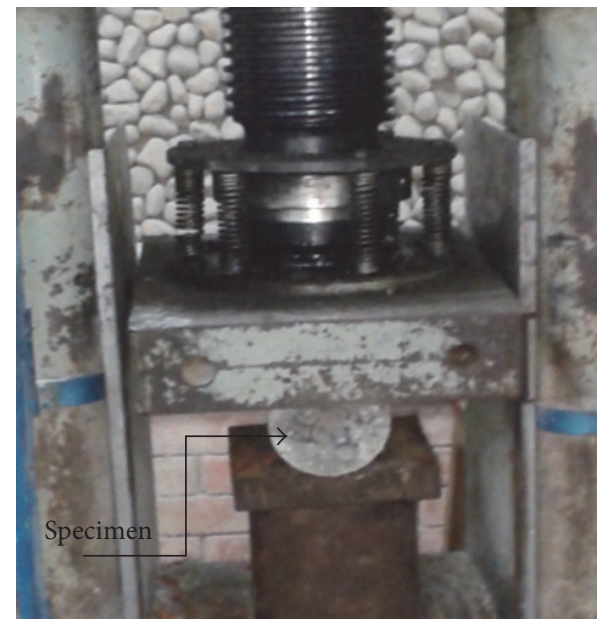

(b)

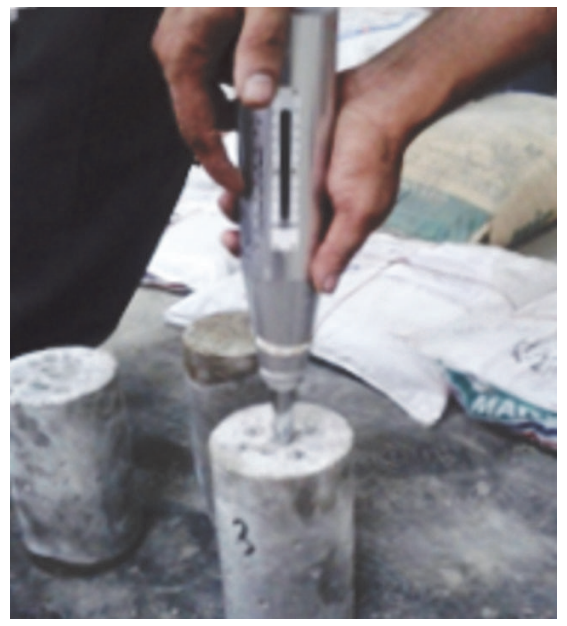

(c)

FIgURE 4: (a) Compressive strength and stress-strain test, (b) tensile strength test, and (c) nondestructive test.

$200 \mathrm{~mm}\left(8^{\prime \prime}\right)$ diameter in bottom is filled by 3 layers with 25 times temping on each layer following ASTM C143 [38]. Diameter of the temping rod was $16 \mathrm{~mm}\left(5 / 8^{\prime \prime}\right)$. Concrete specimens have been properly compacted following the specification of ASTM C 1435-99 [39]. Each and every cylindrical specimen is compacted by the vibrator. After compaction of these specimens, scaling and hammering have been made to get a void-free surface of the specimens. In this study, concrete cylinder with a dimension of $100 \mathrm{~mm} \times 200 \mathrm{~mm}$ $\left(4^{\prime \prime} \times 8^{\prime \prime}\right)$ is made as specimens. Curing of the specimens is completely ensured after the casting. Under water curing method is applied to ensure adequate moisture and temperature as required specification of ASTM C192/C192M-02 [40]. Figure 3 shows the mixing and workability measurement procedure for concrete specimens.
2.4. Testing of Concrete. All tests are conducted at the ages of 7, 14, and 28 days. Crushing strength of concrete and splitting tensile strength are determined by using Universal Testing Machine (UTM) of $1000 \mathrm{kN}$ with a loading rate of $4 \mathrm{kN} / \mathrm{sec}$ over the specimens. Figures $4(\mathrm{a})$ and $4(\mathrm{~b})$ show the procedure of compressive and tensile strength test of concrete, respectively. The cylinder specimen is capped with plastic on the cast face to confirm parallel loading surfaces of the test specimens and is maintained at constant height for all cylinder specimens. ASTM C39M-03 [41] and ASTM C496M-04 [42] are followed for compressive and tensile strength tests, respectively. Nondestructive test are carried out by Schmidt hammer with and angle of the inclination is $\alpha=-90^{\circ}$. A minimum of ten numbers of reading of nondestructive tests are performed for both the sides of each 
specimen as shown in Figure 4(c). The average value obtained from these results is termed as strength of concrete. This test is conducted according to ASTM C805 [43]. Under the uniaxial loading, the relationship between stress and strain of concrete specimen has been developed by Desayi and Krishnan [28] and Carreira and Chu [25] for stone aggregate concrete depending on the experimental data. In this study, a strain gauge is used to measure the strain of specimen under a uniform loading rate. The gauge length is used 3 inch. A compressometer prepared with a dial gauges common in the laboratory is used to collect the deformation over the middle half of the cylinder as shown in Figure 4(a). The rate of applied load is slow and an initial load of around $40 \mathrm{kN}$ is employed and released. In addition, testing head is lowered slowly to get it in contact with the specimen. At this stage, the dial gauges are set to zero. Load is increased gradually by adjusting the lever and is controlling the flow of oil simultaneously. All deformations have been measured nearly at every $40 \mathrm{kN}$ load improvement [5]. Strains and corresponding stresses are measured and the average value is reported in the present study. Modulus of elasticity concrete is determined for all cases at the strain level of 0.0005 based on guidelines followed for plain concrete specimen [44]. Since all the specimens are tested in a force-controlled manner, postpeak response of concrete is not detected in the present study.

\section{Experimental Results and Discussions}

In the present study, hardened mechanical properties and fresh concrete properties are determined to perceive the behavior of recycled brick concrete made with different steel fiber replacements.

3.1. Results of Fresh Concrete Properties. In the present study, workability is determined as a fresh concrete property. It is known that workability of concrete made with recycled aggregate is low due to the high moisture absorption capacity. From the experimental results, it can be said that workability of steel fiber RB concrete is lower compared to that of the plain $\mathrm{B}$ and $\mathrm{RB}$ aggregate concrete and the workability decreases with the increase of percentage of fiber replacement as shown in Figure 5.

3.2. Results of Hardened Concrete Properties. Total of five types of tests have been conducted in the current study to evaluate the hardened properties of concrete. These are as follows: crushing strength of concrete $\left(f_{c}^{\prime}\right)$ by destructive test (DT), concrete compressive strength using Rebound hammer (NDT), tensile strength $\left(f_{t}\right)$, Young's modulus (YM), and the stress-strain $(\sigma-\varepsilon)$ behavior of concrete. The results of experimental investigation are given in following subsections.

3.2.1. Concrete Crushing Strength $\left(f_{c}^{\prime}\right)$. Table 5 presents the values of concrete crushing strength $\left(f_{c}^{\prime}\right)$ at 7,14 , and 28 days. A few enhancements on concrete crushing strength $\left(f_{c}^{\prime}\right)$ are observed with the increase of SF additions for all tested ages. Around $6 \%$ to $12 \%$ increase in 28 days strength is observed for $0.5 \%$ addition of SF made with both B and RB. On the

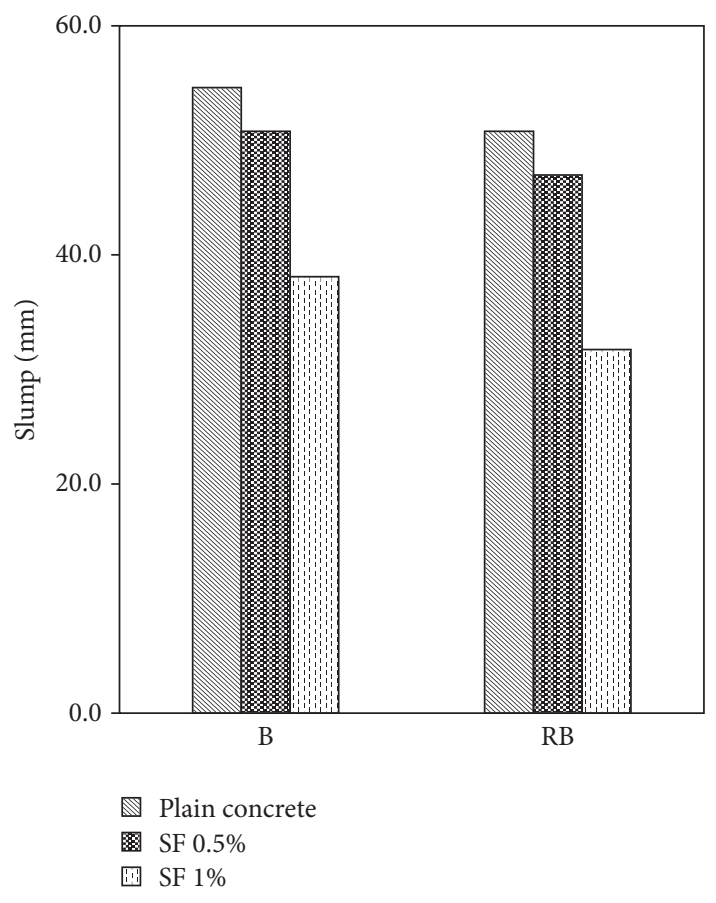

FIGURE 5: Workability of concrete.

other hand, about $8 \%$ to $14 \%$ enhancement is seen for $1 \%$ addition of SF made with both B and RB compared to that of the control case. Effect of aggregate types on compressive strength of concrete has been shown in Figure 6. It is seen that all values are sitting above the line of equity and towards the compressive strength made with B aggregate. In all cases, about $10 \%$ to $18 \%$ enhancement of strength is observed.

3.2.2. Concrete Compressive Strength by Using Rebound Hammer $\left(f_{n d t}\right)$. The result of investigation using nondestructive test (NDT) of concrete is shown in Table 5 for the specimen ages from 7 to 28 days. A significant enhancement is observed for compressive strength for different fiber additions. About $20 \%$ to $30 \%$ increase in 28 days compressive strength is observed for $0.5 \%$ and $1 \%$ SF addition in comparison to that of the control case made with brick aggregate. Similar trend is observed for concrete made with recycled brick aggregates. The relationship of compressive strength of concrete by using nondestructive tests (NDT) and destructive test (DT) of steel fiber (SF) reinforced concrete is being proposed as shown in Figure 7. It is obtained that crushing strength of concrete (DT) is 1.55 times more than that determined by using nondestructive tests (NDT). From the experimental results, it is seen that NDT tests provide conservative values for this case of study. Cylinder strength test provides the actual strength of the concrete specimens. To get the actual strength of concrete, NDT values shall be magnified by a factor of 1.45 for the tested concrete. The equation will be valid only for the concrete made with brick, recycled brick aggregates, and SFRC made up to $1 \%$ addition of steel fiber. Therefore, the 


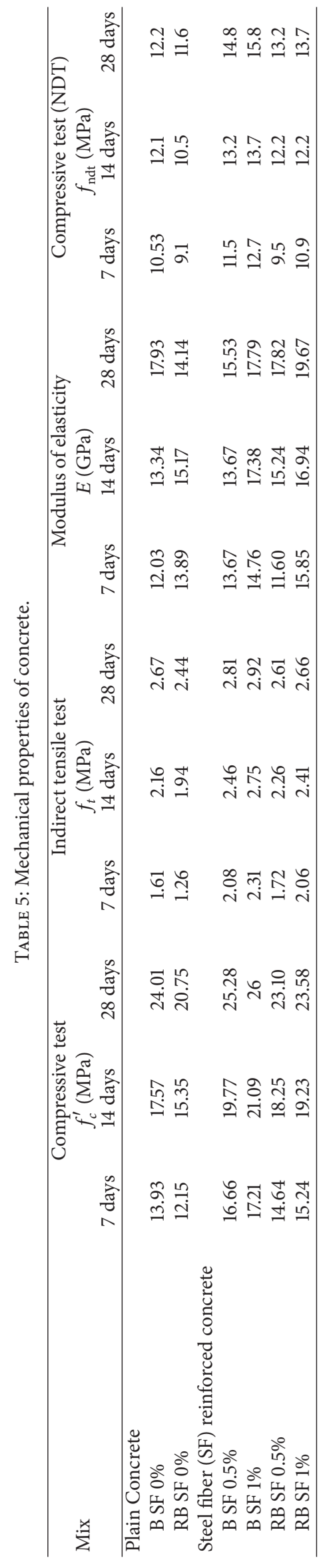




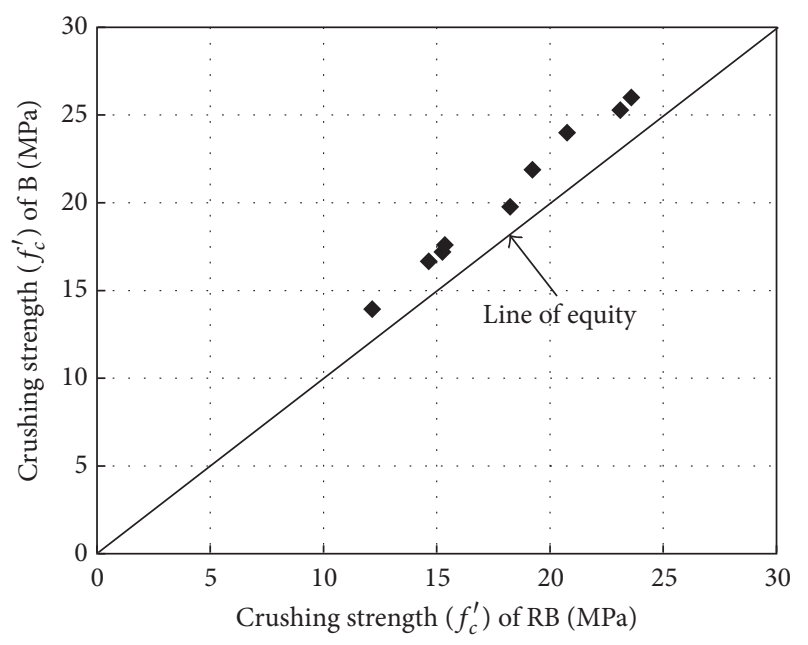

Figure 6: Compressive strength of concrete.

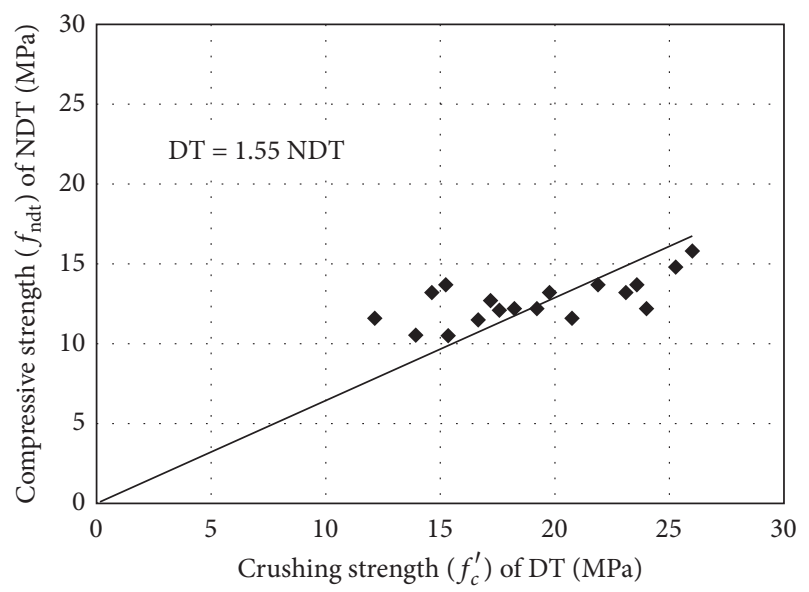

Figure 7: Relationship between NDT and DT.

relationship between the NDT and DT strength of concrete can be stated as follows:

$$
\mathrm{DT}=1.55 \mathrm{NDT},
$$

where NDT is nondestructive compressive strength of concrete and DT is destructive crushing strength of concrete.

3.2.3. Tensile Strength of Concrete $\left(f_{t}\right)$. Effect of SF additions on tensile strength of concrete made with $\mathrm{B}$ and $\mathrm{RB}$ aggregates is presented in Table 5 . Tensile strength $\left(f_{t}\right)$ of concrete is slightly improved for concrete with different SF additions. Around $5 \%$ to $10 \%$ increase in 28 days $f_{t}$ is observed for $0.5 \%$ and $1 \%$ addition of SF made with both $\mathrm{B}$ and $\mathrm{RB}$ aggregates compared to the control case. Nevertheless, effect of aggregate types on tensile strength has been shown in Figure 8 . It is seen that all values are above the line of equity and towards the tensile strength made with B aggregate. In all cases, about $10 \%$ uplift of strength is observed. The variation of $f_{t}$ made of reinforced concrete with $f_{c}^{\prime}$ is presented in Figure 9. Depending on the experimental data of SFRC made with $\mathrm{B}$ and $\mathrm{RB}$ aggregates, the following relationship is

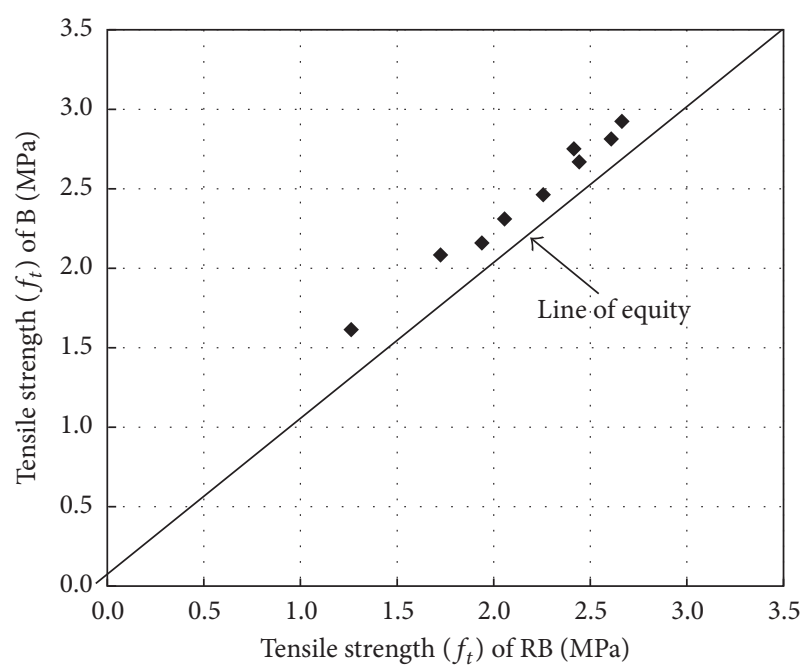

FIgURE 8: Tensile strength of concrete.

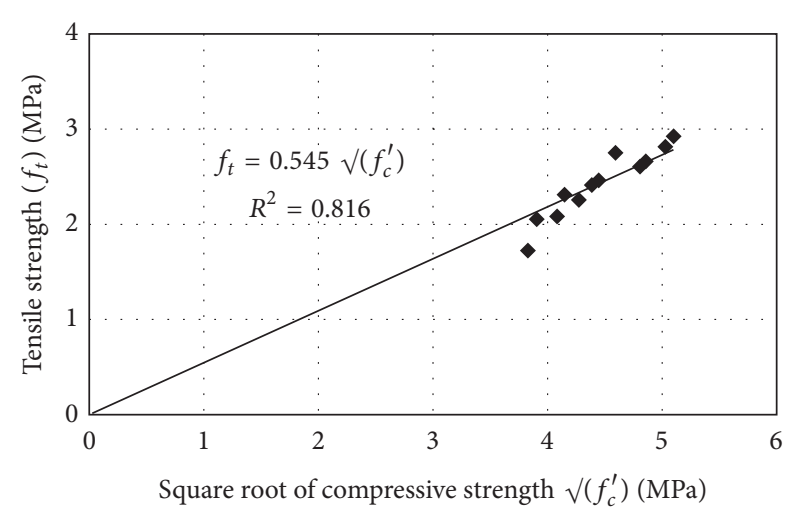

FIGURE 9: Relationship between tensile and compressive strength.

submitted between tensile strength and compressive strength of concrete. This equation will be valid up to $1 \%$ addition of steel fiber.

$$
f_{t}=0.545 \sqrt{ } f_{c}^{\prime},
$$

where $f_{c}^{\prime}$ is compressive strength of concrete in MPa and $f_{t}$ is tensile strength of concrete in MPa.

3.2.4. Modulus of Elasticity (YM) of Concrete. Effect of steel fiber (SF) additions on modulus of elasticity of concrete made with $\mathrm{B}$ and $\mathrm{RB}$ aggregates is evaluated for 7 days, 14 days, and 28 days and is presented in Table 5. It is seen that modulus of elasticity of RB aggregate concrete is significantly improved (around 40\%) for concrete with SF addition of 1\%. The effect of variation of modulus of elasticity is shown in Figure 10. All values are more or less equal to the line of equity.

3.2.5. Stress-Strain Behavior of Concrete. Effect of SF additions on the stress-strain behavior of $\mathrm{B}$ and $\mathrm{RB}$ aggregate concrete is observed for 7 days, 14 days, and 28 days and is shown in Figures 11, 12, and 13, respectively. It is seen that strain taken capacity of both $\mathrm{B}$ and $\mathrm{RB}$ aggregate concrete is 


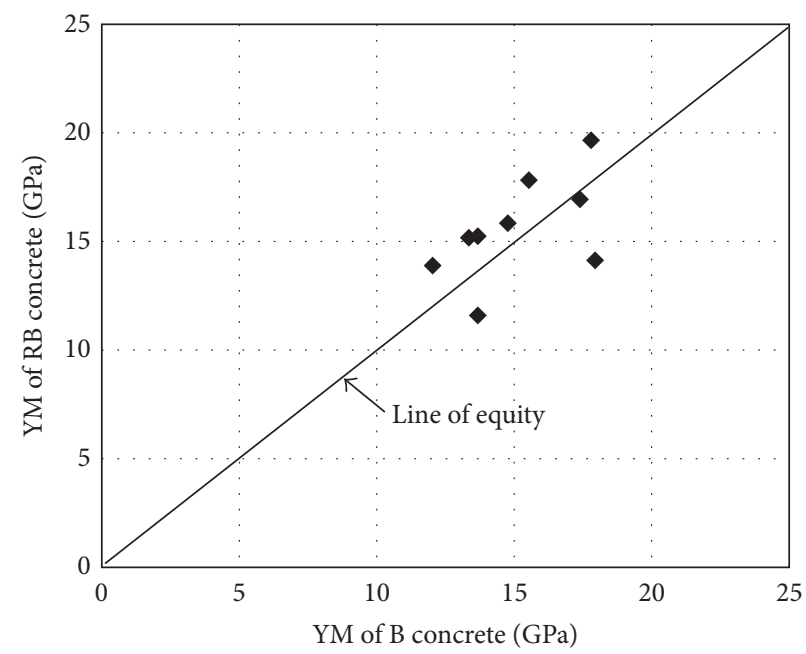

FIGURE 10: Modulus of elasticity of concrete.

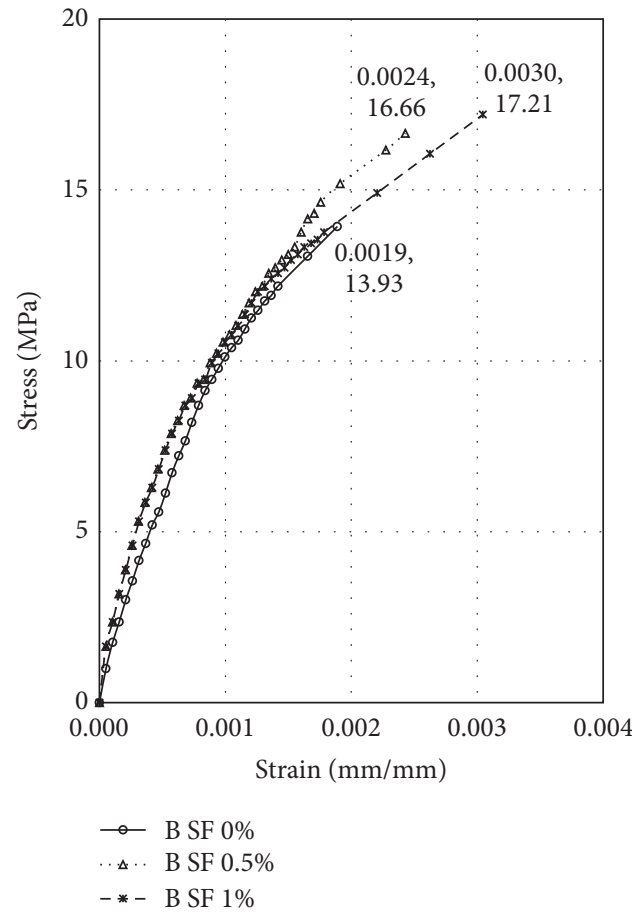

(a)

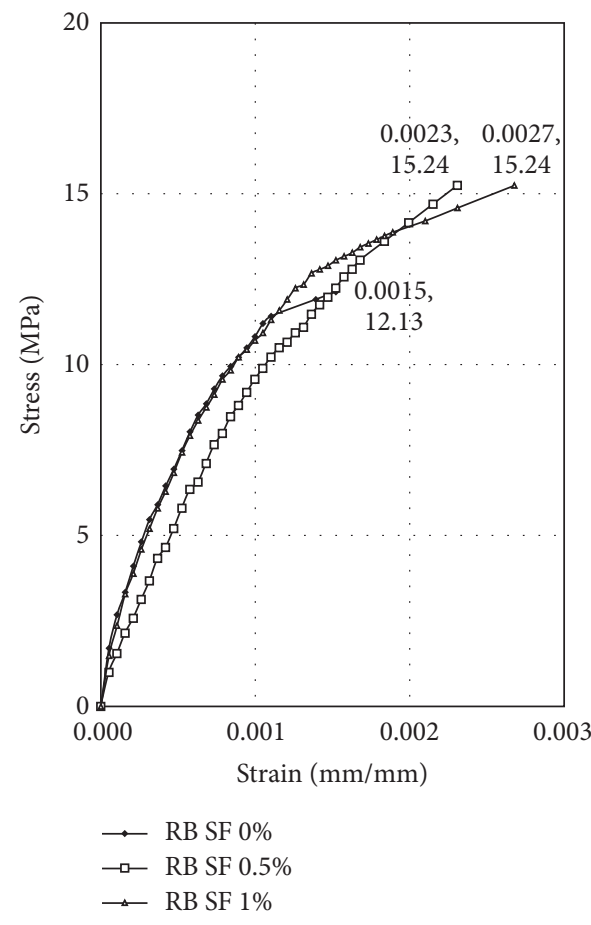

(b)

FIGURE 11: Stress-strain diagram at 7 day; (a) B aggregate and (b) RB aggregate.

significantly improved for concrete made with different SF additions. Rupture strain limit ranging between $30 \%$ and $60 \%$ and $50 \%$ and $80 \%$ is seen for $\mathrm{B}$ and $\mathrm{RB}$ concrete made with $0.5 \%$ and $1 \%$ addition of steel fiber at 7 day, respectively. It is also seen that effect of $1 \%$ addition of SF is more than that of $0.5 \%$ SF compared to the control case. There is a huge enhancement in capacity also observed for concrete at 14 days for both cases. This enhancement is observed almost 2 to 2.3 times for B and RB concrete made with $0.5 \%$ and $1 \%$ additions of steel fiber, respectively, compared to the control case. However, about $80 \%$ increase in strain taken capacity for
$1 \%$ additions of SF in 28 day's $\mathrm{B}$ and $\mathrm{RB}$ concrete is observed. It is also seen that effect of $0.5 \%$ additions of SFRC made with recycled brick (RB) is less compared to the same SF additions of SFRC made with fresh brick aggregate (B).

3.2.6. Fractured Surface of the Specimen. Figure 14 shows the failure surfaces in compressive and tensile strength tests of concrete made with both fresh and recycled brick aggregates. The failure mode of plain concrete is relatively brittle for both tensile and compression tests. Relatively ductile failure 


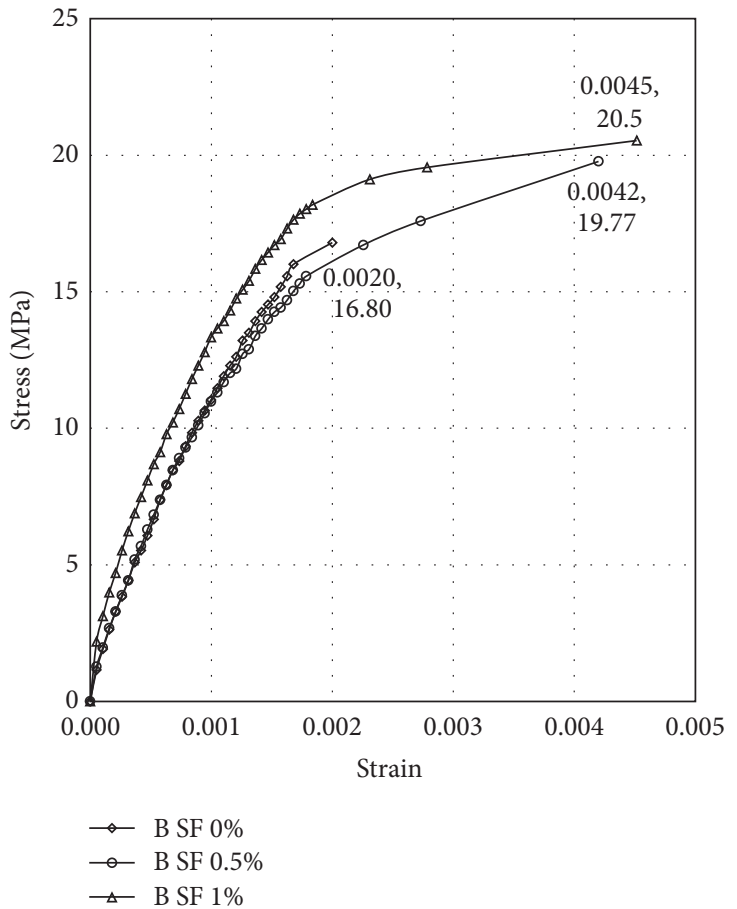

(a)

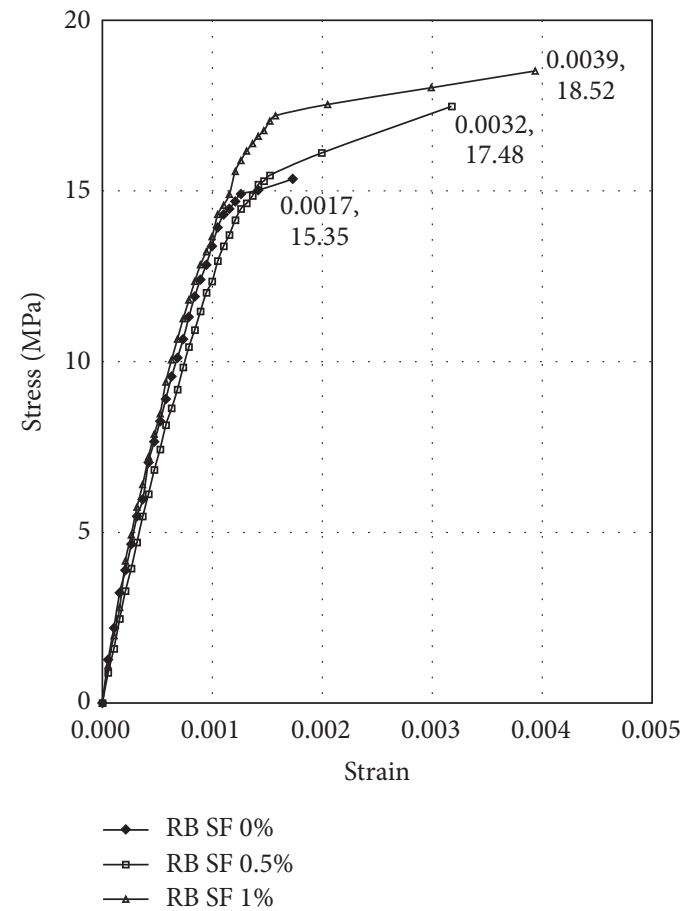

(b)

FIGURE 12: Stress-strain diagram at 14 day; (a) B aggregate and (b) RB aggregate.

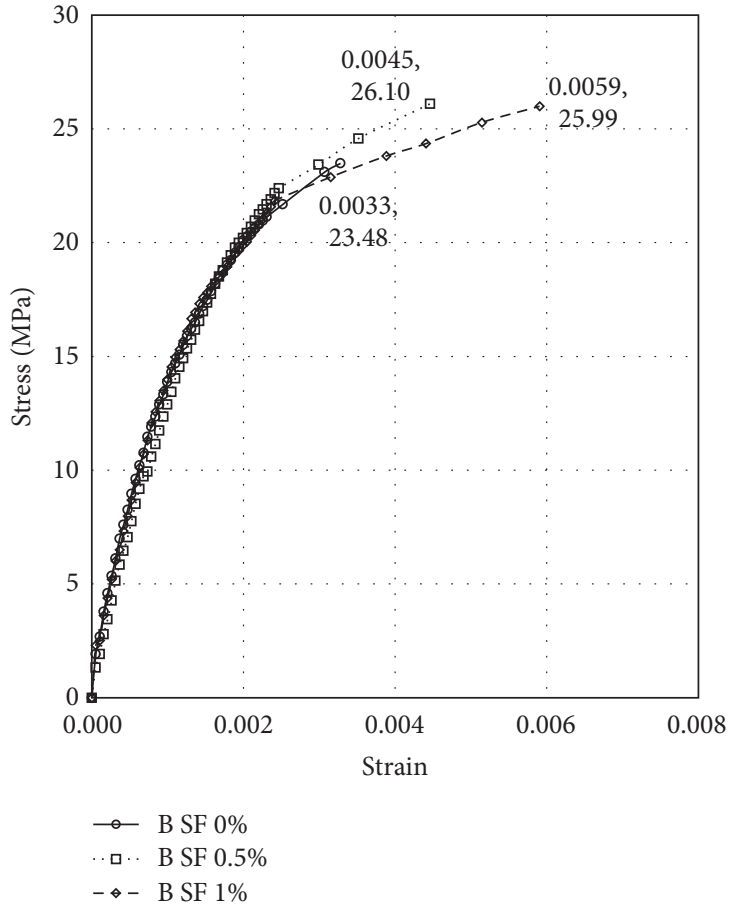

(a)

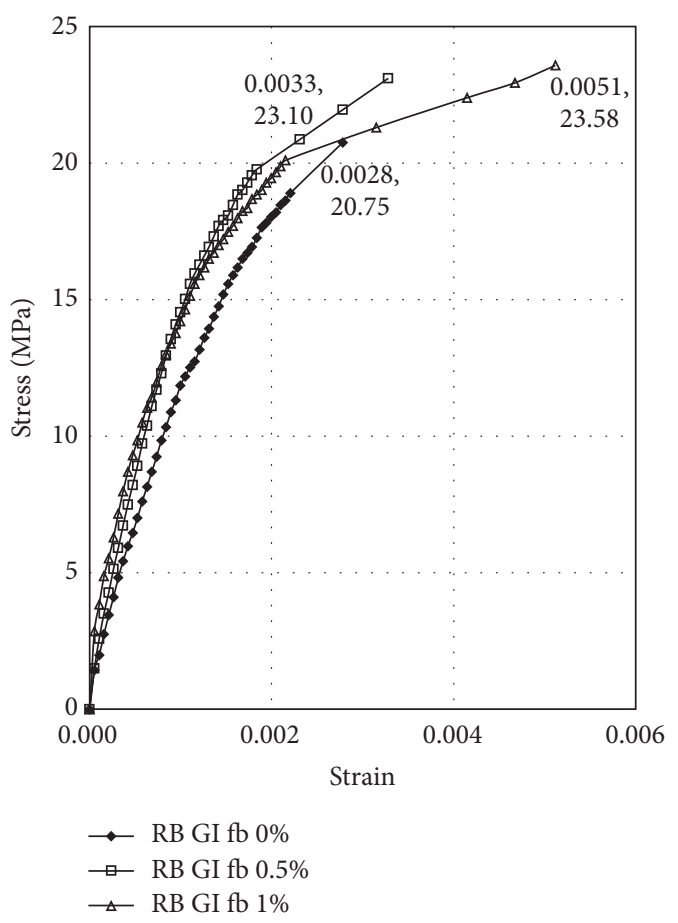

(b)

FIGURE 13: Stress-Strain diagram at 28 day; (a) B aggregate and (b) RB aggregate. 


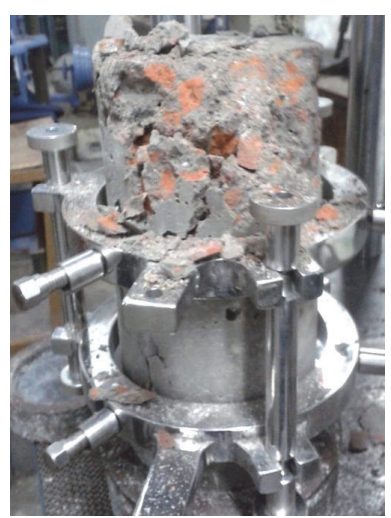

(a)

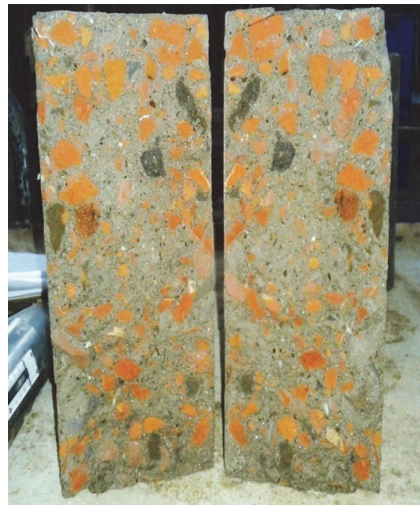

(b)

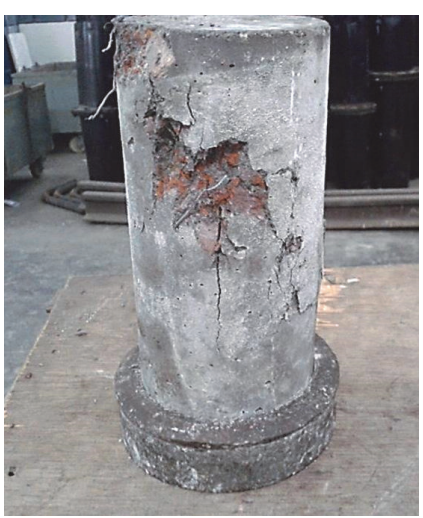

(c)

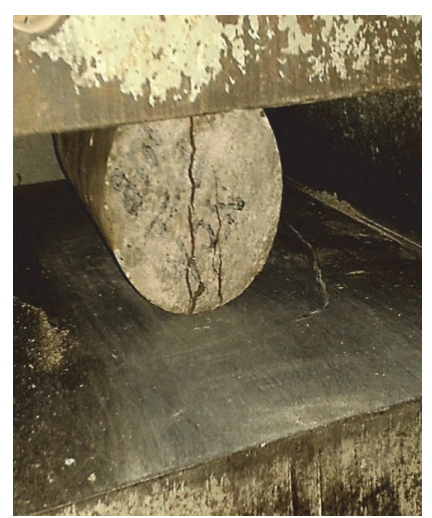

(d)

FIGURE 14: Failure surfaces of cylinder (a \& b) compression and tensile splitting test of plain concrete (c \& d) compression \& tensile splitting test of SFRC.

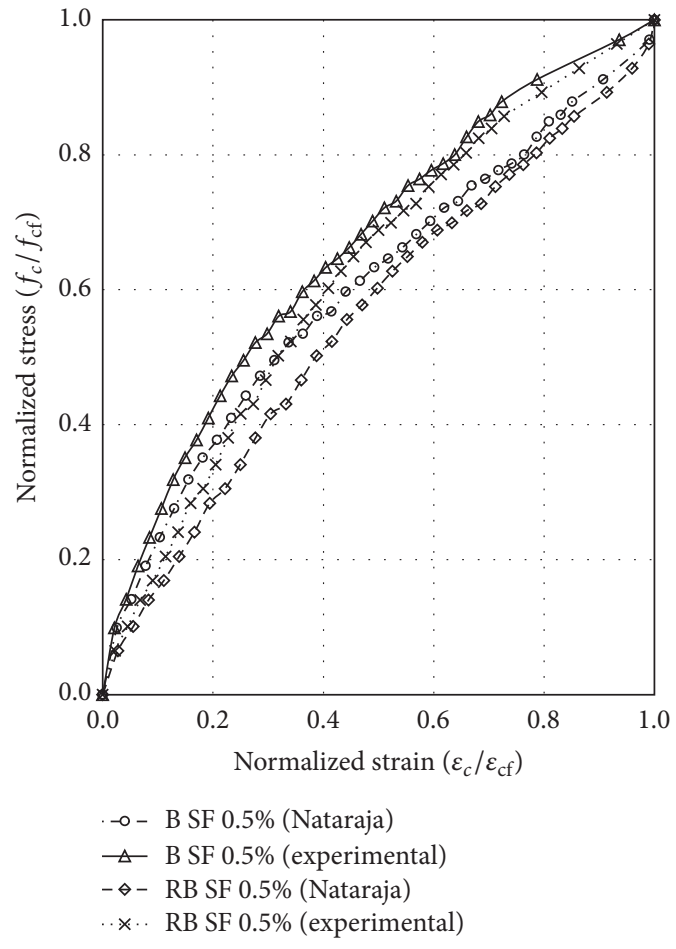

(a)

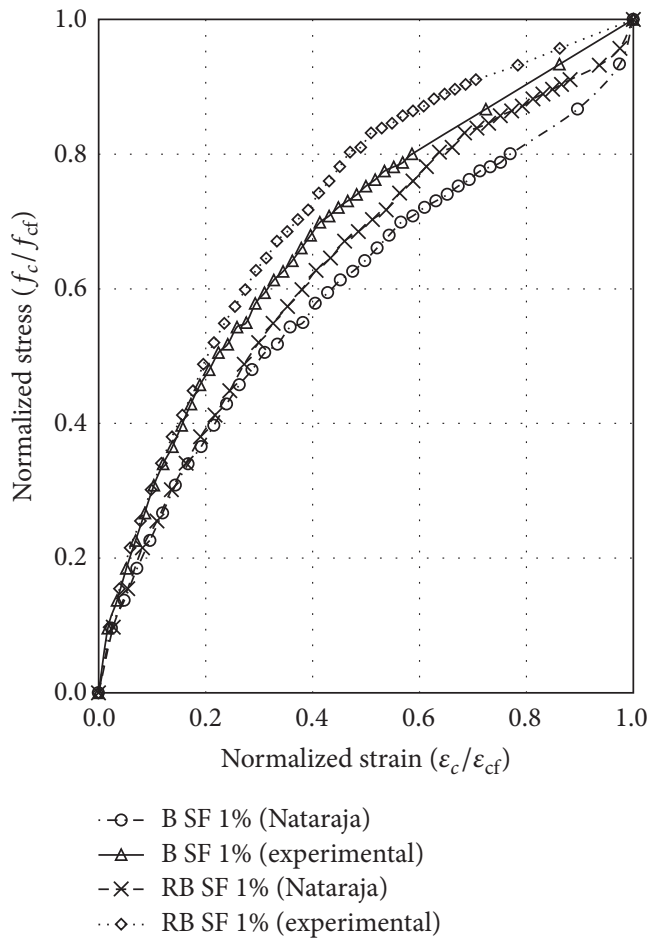

(b)

FIGURE 15: Normalized stress-strain diagram at 7 day; (a) $0.5 \%$ SF and (b) $1 \%$ SF.

is observed for SFRC made with both B and RB compared to the control case ( $0 \%$ replacement of fiber).

3.3. Modeling the Stress-Strain Behavior of SFRC. The stressstrain behavior of the SFRC is modeled using the following analytical expressions proposed by Nataraja et al. [5]:

$$
\begin{aligned}
\frac{f_{c}}{f_{\mathrm{cf}}} & =\frac{\beta\left(\varepsilon_{c} / \varepsilon_{\mathrm{cf}}\right)}{\beta-1+\left(\varepsilon_{c} / \varepsilon_{\mathrm{cf}}\right)^{\beta}}, \\
\beta & =0.5811+1.93(\mathrm{RI})^{-0.7406},
\end{aligned}
$$

where $f_{\mathrm{cf}}$ is compressive strength of fiber concrete; $\varepsilon_{\mathrm{cf}}$ is strain corresponding to the compressive strength; $f_{c}$ and $\varepsilon_{c}$ and stress and strain values on the diagram, respectively. $\beta$ is the dimensionless parameter. $\mathrm{RI}\left(=w_{f} * l / d\right)$ is the reinforcing index that combines the effect of both the fiber weight fraction $\left(w_{f}\right)$ of steel fibers and their aspect ratio $l / d$. The coefficients values in (4) are taken directly from Nataraja et al. [5]. As can be seen in Figures 15, 16, and 17 the use of the analytical expressions is in good agreement with experimental results indicating that they can be extended to steel fiber reinforced concrete containing both $\mathrm{B}$ and $\mathrm{RB}$ aggregates. 


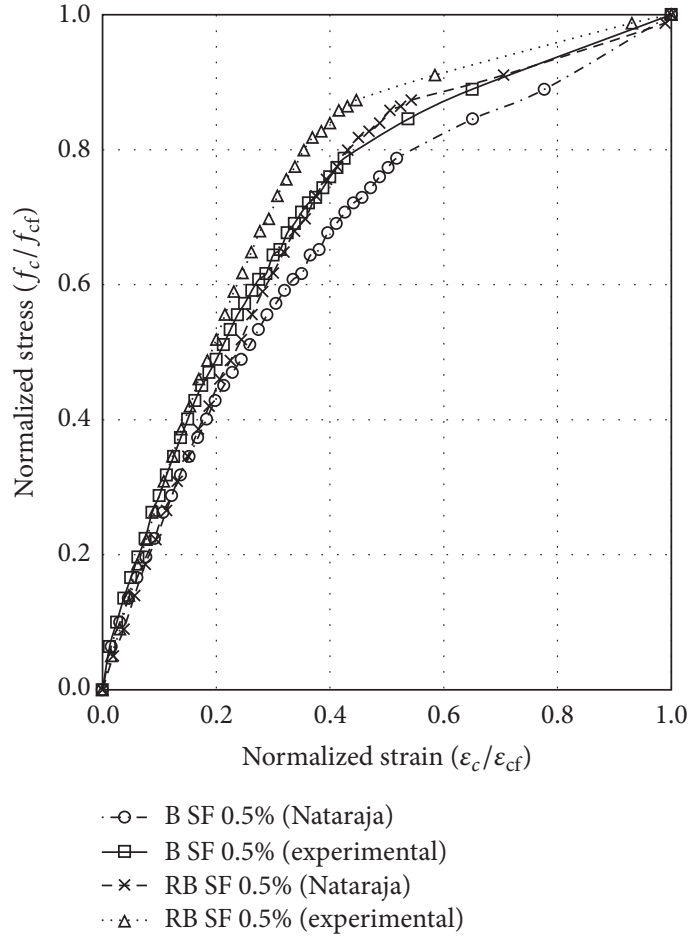

(a)

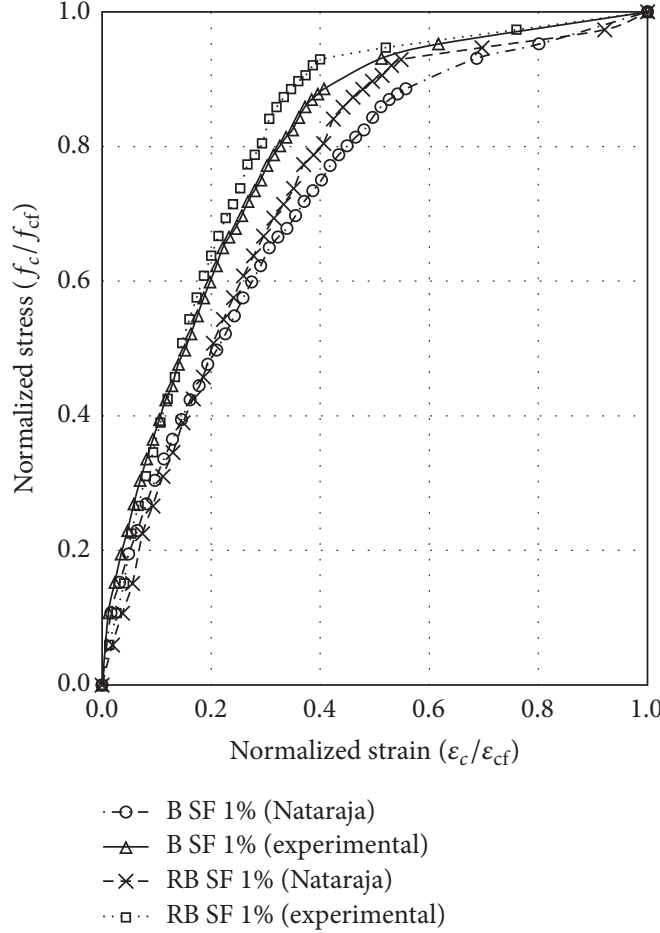

(b)

Figure 16: Normalized stress-strain diagram at 14 day; (a) $0.5 \%$ SF and (b) $1 \%$ SF.
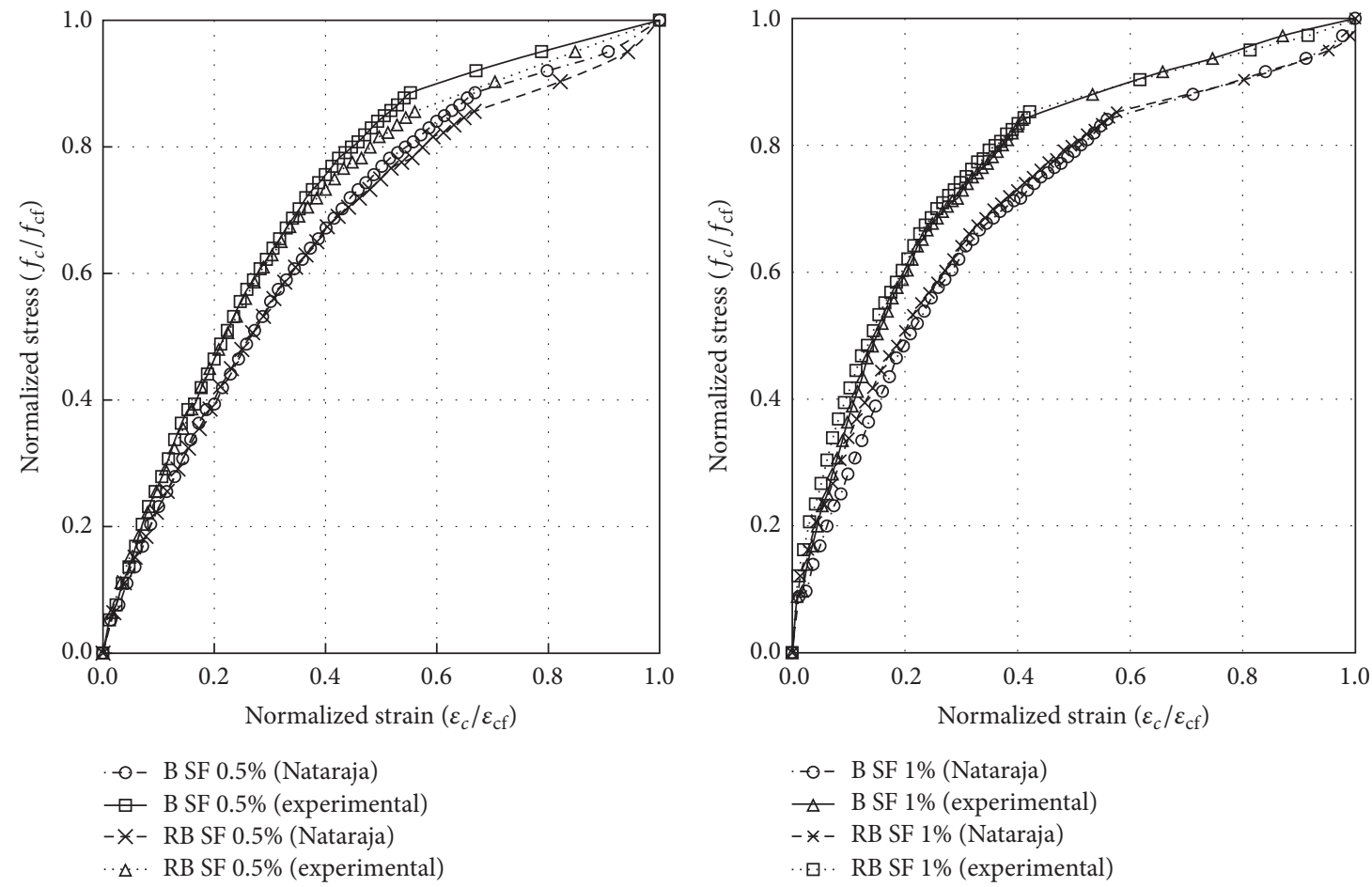

- - B SF $0.5 \%$ (Nataraja)
- B SF $0.5 \%$ (experimental)
$-\star-$ RB SF $0.5 \%$ (Nataraja)
$. \Delta . \quad$ RB SF $0.5 \%$ (experimental)

(a)

(b)

FIgURE 17: Normalized stress-strain diagram at 28 day; (a) $0.5 \%$ SF and (b) $1 \%$ SF. 


\section{Conclusions}

An experimental investigation is carried out to assess the addition of locally available low grade steel fiber reinforcements on the mechanical properties of concrete made with both fresh and recycled brick aggregates. Hooked end steel wires with $50 \mathrm{~mm}$ of length and an aspect ratio of 55.6 are used as fiber reinforcements in a volume fraction of $0 \%$ (control case), $0.50 \%$, and $1.00 \%$. The same gradation of aggregates and water-cement ratio is used to assess the effect of steel fiber in all concrete mixes. All concrete specimens were tested at 7, 14, and 28 days to assess the effect of age on the mechanical properties. A simple analytical model is used to generate the ascending portions of the stress-strain curve of concrete made with both types of aggregates and fiber additions. The main conclusions that can be drawn from the experimental study are stated as follows:

(1) The variation of mechanical strengths such as compressive strength (DT), compressive strength (NDT), tensile strength, stress-strain, Young's modulus considering fresh, and recycled brick aggregates is relatively low. Therefore, recycled brick aggregate can be used effectively as the replacement of fresh brick aggregate in concrete production.

(2) The workability of concrete decreases with the increase of amount of fibers for concrete made with recycled brick aggregates.

(3) About 6\% to $12 \%$ increase in 28 days crushing strength of steel fiber reinforced concrete made with both the fresh and recycled brick aggregates is seen in comparison to the control case $(0 \%$ addition of steel fiber). The effect of addition $1 \%$ fiber on compressive strength is little compared to that of addition of $0.5 \%$ fiber addition. On the other hand, around 5\% to $10 \%$ enhancement in strength is observed at 28 days tensile strength compared to that of the control mix.

(4) The presence of fiber alters the failure mode of concrete specimens. However, the fibers effect is insignificant on the enhancement of concrete compressive strength.

(5) About $20 \%$ to $30 \%$ increase in 28 days compressive strength by using Rebound hammer test of steel fiber reinforced concrete is observed in comparison to that of the plain concrete.

(6) About 20\% to $40 \%$ improvement is shown in Young's Modulus for low grade steel fiber reinforced concrete made with both the fresh brick and the recycled brick aggregate concrete compared to that of the plain concrete.

(7) Rupture concrete strain of fiber reinforced concrete is increased significantly in 28 days. An enhancement of 1.8 times compared to the control mix is observed for $0.5 \%$ and $1 \%$ fiber additions, respectively.

(8) A comparison between the analytical and experimental curves of concrete shows good agreement indicating the possibility of their use to model the behavior of steel fiber recycled brick aggregate concrete.

\section{Conflicts of Interest}

The authors declare that they have no conflicts of interest.

\section{Acknowledgments}

Experimental studies of this paper were carried out under the postgraduate program in Bangladesh University of Engineering and Technology (BUET), Dhaka, Bangladesh. Authors are thankful to all lab technician/assistants of Civil Engineering Department, BUET, for their assistance during the experimental study.

\section{References}

[1] ACI Committee 544, "ACI 544.4R-88, design considerations for steel fiber reinforced concrete," ACI Structural Journal, vol. 85, no. 5, pp. 563-579, 1988.

[2] A. Bentur and S. Mindess, Fibre Reinforced Cementitious Composites, Elsevier Science, London, UK, 1990.

[3] C. D. Johnston, "Steel fiber reinforced mortar and concrete: A review of mechanical properties," in Proceedings of the Fiber Reinforced Concrete ACI, vol. SP 44, Detroit, Mich, USA, 1974.

[4] T. Chien Yet, R. Hamid, and M. Kasmuri, "Dynamic stressstrain behaviour of steel fiber reinforced high-performance concrete with fly ash," Advances in Civil Engineering, vol. 2012, Article ID 907431, 6 pages, 2012.

[5] M. C. Nataraja, N. Dhang, and A. P. Gupta, "Stress-strain curves for steel-fiber reinforced concrete under compression," Cement and Concrete Composites, vol. 21, no. 5-6, pp. 383-390, 1999.

[6] M. A. Chowdhury, M. M. Islam, and Z. Ibna Zahid, "Finite element modeling of compressive and splitting tensile behavior of plain concrete and steel fiber reinforced concrete cylinder specimens," Advances in Civil Engineering, vol. 2016, Article ID 6579434, 11 pages, 2016

[7] V. Afroughsabet, L. Biolzi, and T. Ozbakkaloglu, "Highperformance fiber-reinforced concrete: a review," Journal of Materials Science, vol. 51, no. 14, pp. 6517-6551, 2016.

[8] A. Amin and S. J. Foster, "Shear strength of steel fibre reinforced concrete beams with stirrups," Engineering Structures, vol. 111, pp. 323-332, 2016.

[9] H.-H. Lee, "Shear strength and behavior of steel fiber reinforced concrete columns under seismic loading," Engineering Structures, vol. 29, no. 7, pp. 1253-1262, 2007.

[10] M. Kamran and Nemati, Concrete Technology-Fiber Reinforced Concrete. Final Report, University of Washington, Washington, DC, USA, 2013.

[11] J. Thomas and A. Ramaswamy, "Mechanical properties of steel fiber-reinforced concrete," Journal of Materials in Civil Engineering, vol. 19, no. 5, pp. 385-392, 2007.

[12] S. Goel and S. P. Singh, "Fatigue performance of plain and steel fibre reinforced self compacting concrete using S-N relationship," Engineering Structures, vol. 74, pp. 65-73, 2014.

[13] D. Gielen, J. Newman, and M. K. Patel, "Reducing industrial energy use and $\mathrm{CO}_{2}$ emissions: the role of materials science," MRS Bulletin, vol. 33, no. 4, pp. 471-477, 2008.

[14] M. S. Meddah and M. Bencheikh, "Properties of concrete reinforced with different kinds of industrial waste fibre materials," Construction and Building Materials, vol. 23, no. 10, pp. 31963205, 2009. 
[15] H. Tlemat, K. Pilakoutas, and K. Neocleous, "Stress-strain characteristic of SFRC using recycled fibres," Materials and Structures, vol. 39, no. 287, pp. 365-377, 2006.

[16] Y. Wang, H. C. Wu, and V. C. Li, "Concrete reinforcement with recycled fibers," Journal of Materials in Civil Engineering, vol. 12, no. 4, pp. 314-319, 2000.

[17] M. L. V. Prasad and P. R. Kumar, "Strength studies on glass fiber reinforced recycled aggregate concrete," Asian Journal of Civil Engineering (Building and Housing), vol. 8, no. 6, pp. 677-690, 2007.

[18] T. U. Mohammed, A. Hasnat, M. A. Awal, and S. Z. Bosunia, "Recycling of brick aggregate concrete as coarse aggregate," Journal of Materials in Civil Engineering, vol. 27, no. 7, Article ID B4014005, 2015.

[19] V. Vytlacilova, "The fiber reinforced concrete with using recycled aggregates," International Journal of Systems Applications, Engineering \& Development, vol. 3, no. 5, pp. 359-366, 2011.

[20] A. Rao, K. N. Jha, and S. Misra, "Use of aggregates from recycled construction and demolition waste in concrete," Resources, Conservation and Recycling, vol. 50, no. 1, pp. 71-81, 2007.

[21] J. A. Carneiro, P. R. L. Lima, M. B. Leite, and R. D. T. Filho, "Compressive stress-strain behavior of steel fiber reinforcedrecycled aggregate concrete," Cement and Concrete Composites, vol. 46, pp. 65-72, 2014.

[22] J. Xiao, J. Li, and C. Zhang, "Mechanical properties of recycled aggregate concrete under uniaxial loading," Cement and Concrete Research, vol. 35, no. 6, pp. 1187-1194, 2005.

[23] M. Etxeberria, E. Vázquez, A. Marí, and M. Barra, "Influence of amount of recycled coarse aggregates and production process on properties of recycled aggregate concrete," Cement and Concrete Research, vol. 37, no. 5, pp. 735-742, 2007.

[24] T. H. Wee, M. S. Chin, and M. A. Mansur, "Stress-strain relationship of high-strength concrete in compression," Journal of Materials in Civil Engineering, vol. 8, no. 2, pp. 70-76, 1996.

[25] D. J. Carreira and K.-H. Chu, "Stress-strain relationship for plain concrete in compression," Journal of the American Concrete Institute, vol. 82, no. 6, pp. 797-804, 1985.

[26] P. T. Wang, S. P. Shah, and A. E. Naaman, "Stress-strain curves of normal and lightweight concrete in compression," ACI Materials Journal, vol. 75, pp. 603-611, 1978.

[27] S. Popovics, "A numerical approach to the complete stress-strain curve of concrete," Cement and Concrete Research, vol. 3, no. 5, pp. 583-599, 1973.

[28] P. Desayi and S. Krishnan, "Equation for the stress-strain curve," ACI Materials Journal, vol. 33, no. 3, pp. 345-350, 1964.

[29] E. Hognestad, N. W. Hanson, and D. Mc Henry, "Concrete stress distribution in ultimate strength design," ACI Journal Proceedings, vol. 52, no. 12, pp. 455-480, 1955.

[30] D. A. Fanella and A. E. Naaman, "Stress-strain properties of fiber reinforced concrete in compression," ACI Materials Journal, vol. 82, no. 4, pp. 475-483, 1985.

[31] A. S. Ezeldin and P. N. Balaguru, "Normal- and high-strength fiber-reinforced concrete under compression," Journal of Materials in Civil Engineering, vol. 4, no. 4, pp. 415-429, 1992.

[32] ASTM, "Standard test methods for time of setting of hydraulic cement by Vicat needle," ASTM Standard C191, ASTM, West Conshohocken, Pa, USA, 2007.

[33] ASTM, "Standard test method for normal consistency of hydraulic cement," ASTM C187, ASTM, West Conshohocken, Pa, USA, 2004.
[34] ASTM, "Standard specification for concrete aggregates," ASTM C33-93, ASTM, 1999.

[35] A. S. Brand, J. R. Roesler, and A. Salas, "Initial moisture and mixing effects on higher quality recycled coarse aggregate concrete," Construction and Building Materials, vol. 79, pp. 8389, 2015.

[36] ASTM, "Standard test method for bulk density (unit weight) and voids in aggregate," ASTM C 29, ASTM, West Conshohocken, Pa, USA, 2007.

[37] ASTM, "Standard test method for density, relative density (specific gravity), and absorption of coarse aggregate," ASTM Standard C127, ASTM, 2007.

[38] ASTM, "Slump of hydraulic cement concrete," ASTM C143, ASTM, West Conshohocken, Pa, USA, 2007.

[39] ASTM, "Standard practice for molding roller-compacted concrete in cylinder molds using a vibrating hammer," ASTM C 1435-99, ASTM, 2005.

[40] ASTM, "Standard practice for making and curing concrete test specimens in the laboratory," ASTM C192/C192M-02, ASTM, West Conshohocken, Pa, USA, 2013.

[41] ASTM, "Standard test method for compressive strength of cylindrical concrete specimens," ASTM C39M-03, ASTM, 2003.

[42] ASTM, "Standard test method for splitting tensile strength of cylindrical concrete specimens," ASTM C496M-04, ASTM, 2004.

[43] ASTM, "Standard test method for rebound number of hardened concrete," ASTM C805, ASTM, West Conshohocken, Pa, USA, 2002.

[44] H. N. Arthur, D. David, and W. D. Charles, Design of Concrete Structures, McGraw Hill Education, 13th edition, 2003. 


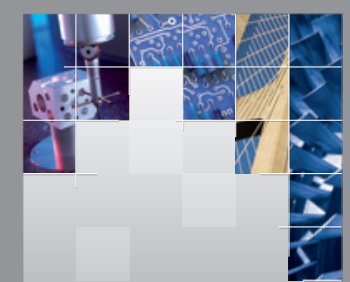

\section{Enfincering}
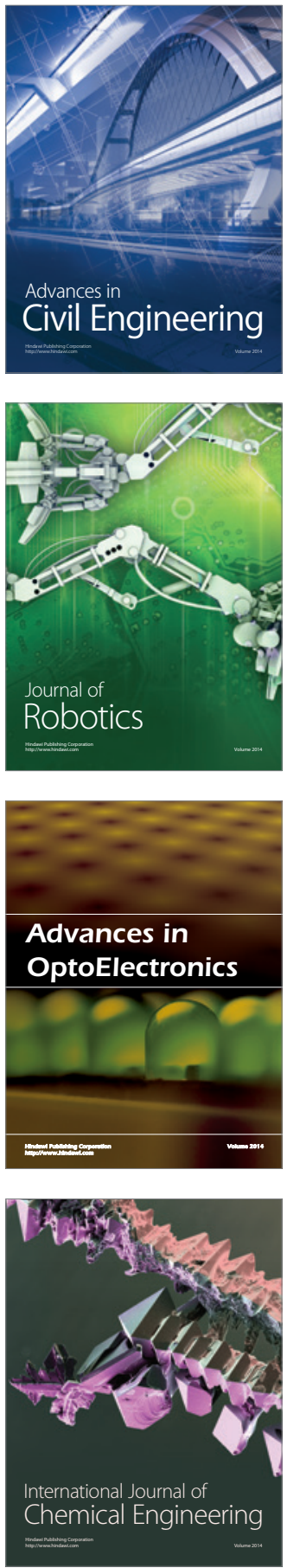

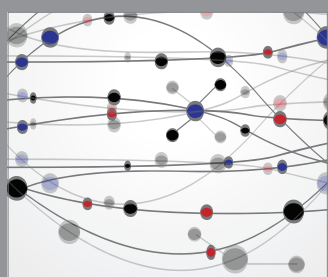

The Scientific World Journal

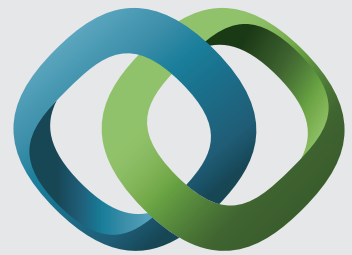

\section{Hindawi}

Submit your manuscripts at

https://www.hindawi.com
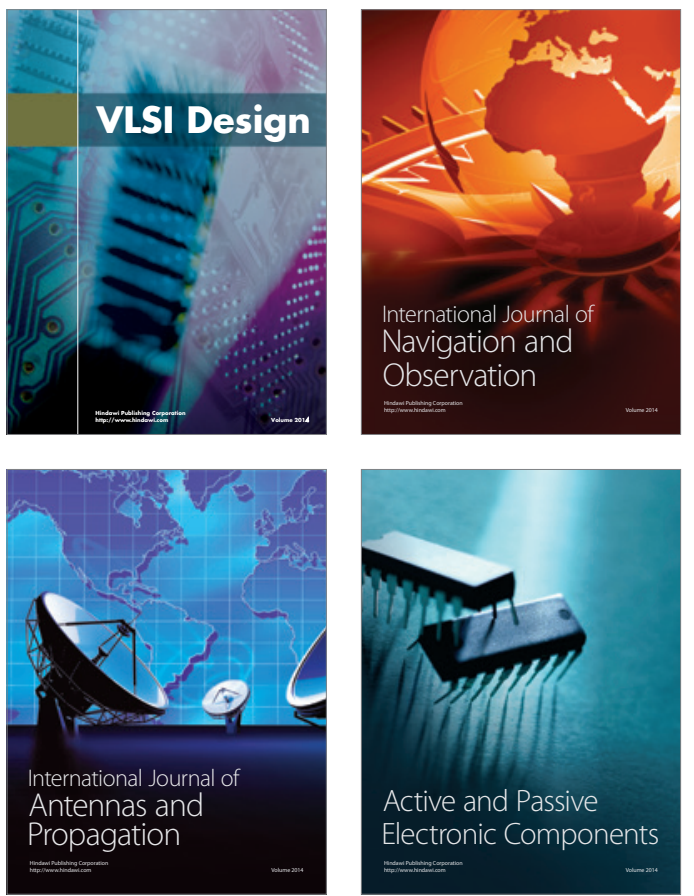
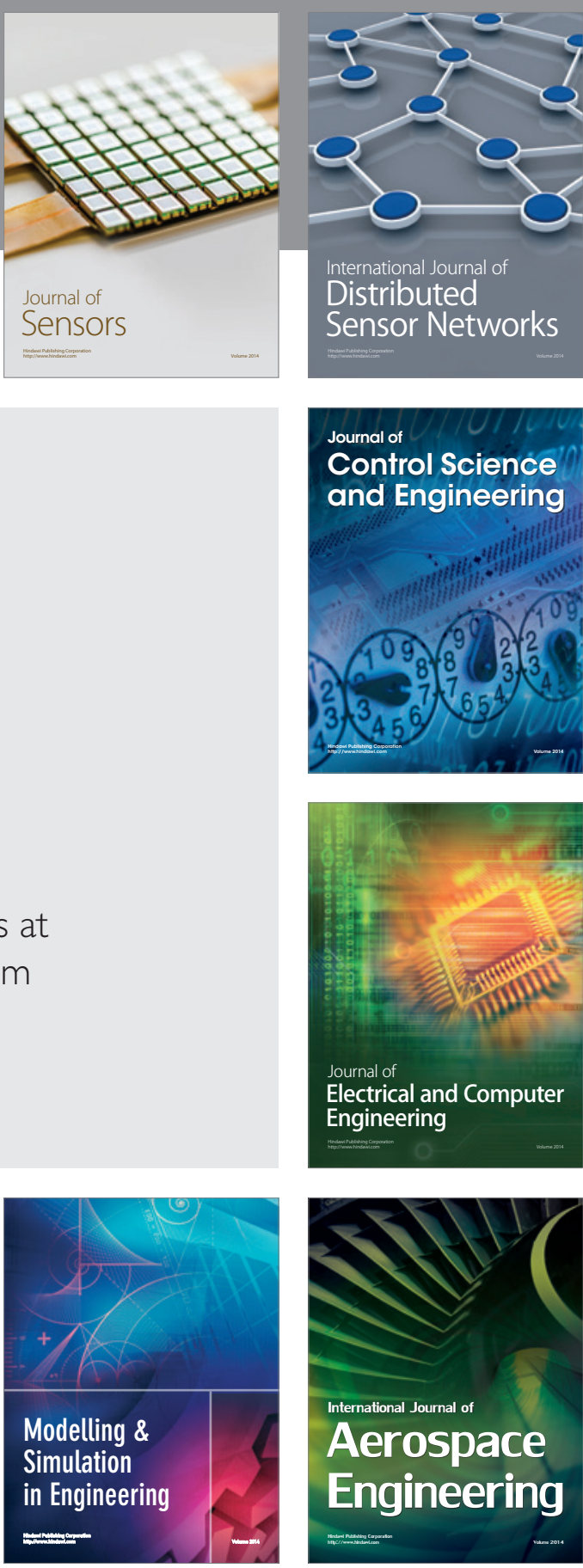

International Journal of

Distributed

Sensor Networks

$-$

Joumal of

Control Science

and Engineering
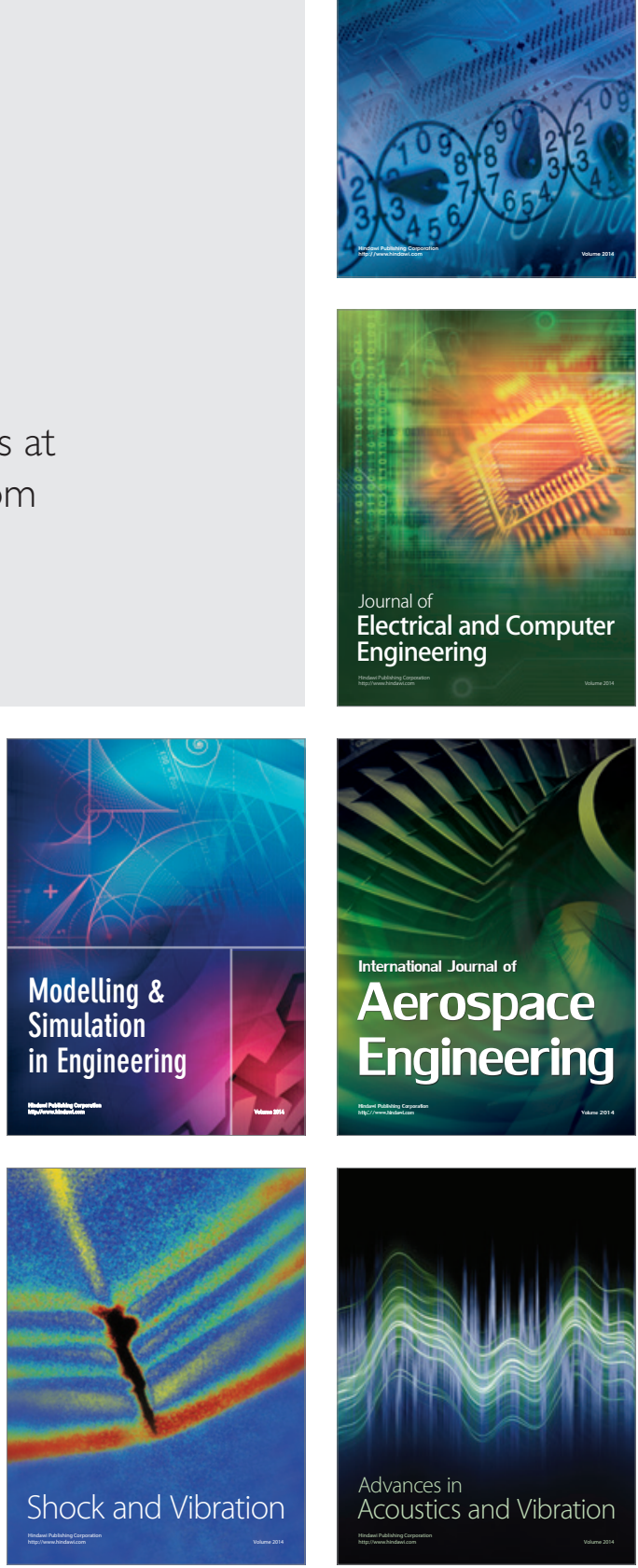